\title{
Role of Farm Real Estate in a Globally Diversified Asset Portfolio
}

\author{
Gilbert V. Nartea \\ Senior Lecturer in Finance \\ Department of Accounting, Economics, and Finance \\ Faculty of Commerce \\ Lincoln University, New Zealand \\ Chris Eves \\ Professor of Property Economics \\ School of Urban Development \\ Faculty of Built Environment and Engineering \\ Queensland University of Technology, Australia
}

Gilbert V. Nartea is a Senior Lecturer in Finance at Lincoln University, New Zealand. He obtained his B.S. in agribusiness management (cum laude) from the University of the Philippines, M.Econ. from the University of New England, Australia and Ph.D in agricultural economics from the University of Illinois at Urbana-Champaign, USA. He was a former Assistant Professor in agribusiness management at the University of the Philippines.

Chris Eves is currently the Professor in Property Economics at Queensland University of Technology. He has undergraduate degrees in Agriculture and Business and his $\mathrm{PhD}$ was completed at University of Western Sydney in the area of rural property investment performance and the development of an Australian rural property investment performance index, which is updated bi-annually. 


\title{
Role of Farm Real Estate in a Globally Diversified Asset Portfolio
}

\begin{abstract}
Purpose - The paper examines the benefits of further diversifying a global portfolio of financial assets with New Zealand farm real estate (FRE).

Design/methodology/approach - We compare efficient sets generated with and without farm real estate using portfolio theory.

Findings - The results show that given the predominantly negative correlation between FRE and financial assets, the risk-return tradeoffs of portfolios of financial assets can be improved significantly. The diversification benefits measured in terms of risk reduction, return enhancement, and improvement in the Sharpe performance ratios are robust under a number of FRE risk-return scenarios as well as under high and low inflationary periods. Using 5- and 10-year rolling periods we also find that FRE is a consistent part of risk efficient portfolios. Consistent with the results reported in Lee and Stevenson (2006) for UK real estate the risk reduction benefits of diversifying with FRE are larger than the risk enhancement benefits.
\end{abstract}

Practical implication - The results suggest that FRE takes on a consistent role of riskreducer rather than a return-enhancer in a globally diversified portfolio. FRE appears to deserve more serious consideration by investment practitioners that it has been accorded in the past.

Originality/value - The study examines the role of direct real estate in a globally diversified portfolio of financial assets.

Key words Global diversification, Farm real estate, New Zealand, Portfolio theory Paper type Research paper 


\section{Role of Farm Real Estate in a Globally Diversified Asset Portfolio}

\section{Introduction}

The poor performance of global stock markets in recent years has ignited renewed interest in alternative investments to enhance return and reduce risk (Lee and Stevenson, 2006) through effective diversification. With increased globalisation one obvious avenue is international equity diversification, the benefits of which have been well documented (see for example, Levy and Sarnat, 1970; Harvey, 1991; Li, et al, 2003; Meyer and Rose, 2003; Fletcher and Marshall, 2004; Phengpis and Swanson, 2004). However, with increased globalisation comes increased economic and financial integration leading to increased positive correlations among international equity markets with the consequent decline in the benefits from international diversification (Kearney and Lucey, 2004).

Real estate returns on the other hand has traditionally been shown to have a low correlation with financial assets and are therefore regarded as excellent vehicles for diversification (see Seiler, Webb and Myer, 1999 for an excellent review). Farm real estate (FRE) in particular appear to have a consistently low correlation with returns from financial assets with several North American studies suggesting the desirability of adding farm real estate (FRE) to a mixed portfolio of financial assets (Barry, 1980, Kaplan, 1985, Young and Barry, 1987, Moss et al., 1987, Lins et al., 1992, Painter, 2000., Eves and Newell, 2007). However few have tested the robustness of these benefits. 
Barry (1980) finds that US farmland has low systematic risk relative to other assets, and is therefore a good candidate for risk reduction in well diversified portfolios. Kaplan (1985) also argues that US farmland's high return and low correlation with US stocks and bonds makes it an ideal asset for diversification. Young and Barry (1987) find Illinois farmland to be negatively correlated with US stocks, corporate, government, and municipal bonds as well as T-bills and certificates of deposit. Using mean-variance (EV) analysis they show that Illinois farmers could reduce the relative variability of their farm's rate of return some 15 to 25 per cent by allocating up to 25 per cent of their investment portfolio in financial assets. Moss et al. (1987) likewise find that aggregate US farmland is negatively correlated with corporate and government bonds and T-bills and moderately positively correlated with US stocks. Using EV analysis they form riskefficient portfolios that contained 30 to 68 per cent farmland. Lins et al. (1992) also used EV analysis to investigate the effect of adding US farmland and international stocks to a portfolio of US stocks, bonds and business real estate. They find that portfolio performance could be enhanced by including US farmland in the mix. In Canada, Painter (2000) investigates the benefits of adding Saskatchewan farmland to a portfolio of Canadian and international stocks and Canadian T-bills and longterm bonds. He finds that Saskatchewan farmland is negatively correlated with all financial assets considered in the study and is part of the efficient set for medium and high-risk portfolios.

In New Zealand Nartea and Dhungana (1998) report that NZ dairy farm returns are negatively correlated with NZ bond yields and weakly positively correlated with NZ share returns and suggest that farmers look towards diversifying into financial assets. Nartea and Pellegrino (1999) use EV analysis to investigate 
the benefits of diversifying a sheep and beef farm with investments in New Zealand shares. They document a negative correlation between farmland and share returns over the period 1966 to 1996 and report that a portfolio consisting of 16 to 25 per cent shares and 75 to 84 per cent farmland could reduce risk by as much as 20 per cent as compared with investing in farmland alone. Updating Nartea and Pellegrino's (1999) data set, and incorporating investor risk preferences, Nartea and Webster (2008) use data from 1966-2003 and report that NZ farmers with high degrees of risk aversion would gain utility by adding NZ financial assets to their portfolio dominated by farm real estate. In a related study, Nartea and Eves (2008) using data from 1995-2005 found that adding direct real estate, in particular retail property and farm real estate, to a portfolio of NZ financial assets provided significant return enhancement and risk reduction benefits that are robust even when real estate return variance is increased six-fold or when real estate returns are reduced by $20 \%$, suggesting that real estate can reasonably be expected to be a consistent part of risk efficient portfolios.

In spite of these findings anecdotal evidence suggests that investment practitioners allocate a negligible portion of their portfolios to farm real estate. One reason for this could be the suggestion that real estate form part of mixed asset portfolios in theoretical studies due to the understatement of real estate risk and/or due to inflation (Webb and Rubens,1987; Michaud, 1989; Fisher et al.,1994; Corgel and de Roos, 1999).

The purpose of this paper is three-fold. First we quantify the benefits of adding New Zealand farm real estate to an already diversified mixed portfolio of international financial assets using EV analysis of modern portfolio theory. Second we test the robustness of these benefits under several scenarios and third, we test 
the consistency of FRE being part of the efficient set. Our approach is to use historical data for returns of different asset classes to generate risk efficient sets. We then compare efficient sets generated with and without farm real estate to determine the magnitude of return enhancement keeping risk constant, as well as the level of risk reduction while maintaining level returns. We also compare mean Sharpe ratios generated from equally spaced portfolios in the efficient sets. Then we perform robustness tests of diversification benefits under several FRE riskreturn scenarios. We also test the robustness of diversification benefits for two periods, one characterised by low inflation and the other by high inflation. Finally we use 5- and 10-year rolling periods to test if FRE is a consistent part of the efficient set.

\section{Research Design and Data}

\subsection{The Model}

We start with a portfolio of New Zealand T-bills, bonds, and shares and we show the benefit of diversifying globally with eight international equity markets. Then we investigate the benefits of adding direct farm real estate (FRE) (as opposed to Real Estate Investment Trusts) to the mix. This increased diversification is expected to expand the risk efficient frontier by shifting it northwest. Hence we investigate the incremental impact of the addition of FRE by examining the magnitude by which portfolio returns increase keeping risk constant, and the amount by which portfolio risk is decreased without diminishing returns. We also measure the improvement in the Sharpe ratio (Sharpe, 1966) which is defined as excess return per unit of risk. Excess return is the return above the risk-free rate and risk is defined as standard deviation of returns. 
We use the traditional full-covariance EV analysis as developed by Markowitz (1952) to form risk efficient investment portfolios. A risk efficient portfolio is defined as a combination of assets which maximises the expected returns for a given level of risk (measured as variance or standard deviation), or one that minimises the risk level for a desired expected rate of return. Risk-efficient portfolios can be generated by solving the following quadratic formulation:

$$
\operatorname{Min} \sigma_{p}=\left(\sum \sum x_{i} \sigma_{i j} x_{j}\right)^{0.5}
$$

subject to

$\begin{array}{lll}\sum x_{i} E\left(r_{i}\right) & \geq & Z \\ \sum x_{i} & = & 1 \\ x_{i} & \geq & 0\end{array}$

where $\sigma_{p}$ is the portfolio standard deviation, $x_{i}$ is the proportion of asset $i$ in the portfolio, $E\left(r_{i}\right)$ is the expected return of asset $i, \sigma_{i j}$ is the covariance between assets $i$ and $j$ (variance of asset $i$ if $i=j$ ), and $Z$ is the expected portfolio return, which is varied parametrically to obtain the risk-efficient set. The last constraint restricts short-selling in this model to reflect the fact that FRE cannot be sold short.

Time series data relating to annual rates of return on shares, bonds, T-bills and FRE are obtained for the period spanning 1989 to 2005. Another data series of annual rates of return on shares and FRE is gathered for the period 1974-2003 for the robustness test involving high and low inflationary periods. The period 19741988 is typified by high inflation while $1989-2003$ is characterised by low inflation. Annual rates of return are calculated as the sum of the current return and the capital gain expressed as:

$$
R_{i t}=D_{i 1}+\left(V_{i 1}-V_{i 0}\right) / V_{i 0}
$$


where $R_{i t}$ is the total rate of return in year $t$ for the $i$ th asset, $D_{i 1}$ is the current return, $V_{i 0}$ is the asset value at the beginning of each year, and $V_{i 1}$ represents the asset value at the end of the year.

We make no distinction between realised and unrealised capital gains since retaining the asset and earning only 'unrealised' capital gain, is no different from selling it at year end, "realising" the capital gain, and immediately reinvesting by buying the asset back.

\subsection{Ordinary shares, government bonds, and T-bills}

Ordinary shares are represented by country indices as reported in Datastream. The country indices that are considered in this study represent Austral-Asia (New Zealand, Australia, Hong kong, Japan, and Singapore), North America (U.S.), and Europe (France, Italy, and the U.K.) All returns are converted to NZ\$. Bonds are represented by Datastream NZ ALL lives government bond index and T-bills are represented by the NZX 90 Bank Bill Index obtained from the New Zealand Exchange (NZX).

\subsection{Farm real estate}

Farm real estate is represented by sheep and beef operations on grazing farmland. Sheep and beef operations are the dominant agricultural activity in NZ covering approximately two-thirds of the 15.5 million hectares of land under occupation as of 2004 .

The total return on farm real estate is the sum of the production rate of return and the capital gain. The production rate of return is the weighted average rate of return on assets for all classes of sheep and beef farms as reported in the New Zealand Sheep and Beef Farm Survey (New Zealand Meat and Wool Board 
Economic Service, various dates). The Survey involves roughly 500 to 550 farms per year. A sheep and beef farm is defined as a privately operated farm which winters at least 750 sheep or their equivalent stock units in terms of sheep and cattle stock. At least 80 per cent of the stock units on the property had to be sheep and/or beef cattle and at least 70 per cent of the farm revenue had to be derived from sheep or sheep and beef cattle. To the extent that farm rates of return are estimated from group averages, our results are likely to understate the degree of variability faced by the individual farm. This issue will be addressed in the robustness tests to follow. The capital gain component is represented by the annual percentage change in the grazing land price index (Valuation New Zealand, various dates).

\section{Empirical Results}

\subsection{Comparative risk and return measures}

Table 1 shows the mean, standard deviation, and coefficient of variation $(\mathrm{CV})$ of the annual returns of farm real estate, T-bills, bonds, and the nine equity markets from 1989 to 2005. The data reveals that with the exception of Hong Kong and France, FRE outperformed all share markets considered earning a higher mean annual rate of return at a lower standard deviation or risk. On a risk-adjusted basis, FRE clearly outperformed all share markets. Only 90 day T-bills and bonds outperformed FRE on a risk-adjusted basis. This is clearly illustrated in Table 1 by the reward-to-risk ratio which is the expected return per unit of risk (ie mean annual rate of return divided by the standard deviation). Table 1 shows that farm real estate has a reward-to-risk ratio that is $33 \%$ better than Australian equities which posted the highest reward-to-risk ratio among the share markets considered in the study. 


\section{[Insert Table 1 about here]}

Using the coefficient of variation as a measure of risk, T-bills and bonds are the least risky among the assets considered followed by FRE. Share returns are evidently more variable that T-bills, bonds, and FRE. Among the share markets considered, Japan exhibited the highest variability while Australia had the lowest. The variability of total FRE returns is apparently due to the capital gain component which also accounts for $71 \%$ of total return.

Figure 1 illustrates the relationship among farm real estate and NZ financial assets. FRE returns are clearly more volatile than T-bills and bonds but more stable than NZ equities. FRE returns also appear to have a longer price cycle than financial assets, consistent with the results in other countries (see for example, Painter, 2000).

\section{[Insert Figure 1 about here]}

Figure 2 compares FRE returns with US and Australian share market returns and shows that FRE returns are less variable and also appears to have a longer price cycle than the equity markets.

\section{[Insert Figure 2 about here]}

\subsection{Correlation Matrix}

Table 2 displays the pair wise correlation coefficients of the asset classes and shows that FRE returns are negatively correlated with all equity markets considered except for New Zealand, and are also negatively correlated with T-bills and bonds. These coefficients suggest that significant gains in risk efficiency could be obtained by adding FRE to a mixed portfolio of financial assets. 


\section{[Insert Table 2 about here]}

As a matter of interest, the correlation between share markets ranged from a low of -.18 between New Zealand and Italy to a high of .90 between US and UK. New Zealand and the US also posted among the lowest correlation coefficients at .17. Overall, Table 2 shows the New Zealand share market is negatively correlated with the US and European markets and weakly positively correlated with the Australian and Asian markets, while the US share market appears to be highly correlated with the European markets and weakly correlated with the Australian and Asian markets.

\subsection{Benefits of diversification}

Risk-efficient investment portfolios were obtained by solving equation (1) subject to (2), (3), and (4) for alternative values of $Z$. Based on the risk efficient sets, the benefits of diversification are measured by the magnitude of a) risk reduction, b) return enhancement, and c) improvement in excess return per unit of risk as measured by the Sharpe ratio. Figure 3 shows the efficient frontier for investments involving a) only NZ financial assets, b) NZ financial assets and international equities, and c) NZ financial assets, international equities, and NZ FRE. The efficient frontier comprised only of NZ financial assets is clearly dominated by the frontier which includes international equities. Figure 3 also shows that further gains are possible with the inclusion of FRE in the mix.

[Insert Figure 3 about here]

\subsubsection{Risk reduction}


Table 3 shows the risk reduction benefits of diversifying a mixed asset portfolio of international financial assets with FRE. The risk reduction benefits are determined by comparing risk at points of identical returns for portfolios in the efficient sets with and without FRE. Efficient portfolios without FRE are shown in Panel A while those with FRE are displayed in Panel B. Panel B shows that the risk reduction benefits are economically significant and are most pronounced at portfolio returns in the range of 12 to $15 \%$. Over this range of returns, annual risk levels can be halved by holding FRE in a mixed asset portfolio in amounts ranging from 35 to $67 \%$ of the total mix. In terms of basis points, the benefits are equivalent to a risk reduction of 408 to 886 points. The gains in risk reduction decline sharply at both ends of the efficient frontier, but even at modest allocations of FRE seen at the lower end of the frontier ranging from 9 to $24 \%$ of the total portfolio, reduction in risk still ranges from 11 to $40 \%$ or 34 to 220 basis points.

\section{[Insert Table 3 about here]}

\subsubsection{Return enhancement}

The return enhancement benefits are shown in Table 4 . These benefits are measured by comparing returns of portfolios with and without FRE at identical levels of risk (standard deviation). Panel A shows the efficient portfolios without FRE while Panel B displays the efficient portfolios with FRE. The return enhancement benefits shown in Panel B are also economically significant but are generally lower than the risk reduction benefits. FRE allocation and its marginal impact on portfolio returns is highest for portfolios with risk in the range of 6 to $12 \%$. At these risk levels, an allocation of 54 to $64 \% \mathrm{FRE}$ results in a 17 to $23 \%$ increase in returns or the equivalent of a 228 to 285 basis point increase in annual returns. Like the gains in 
risk reduction, the risk enhancement benefits decline at both ends of the efficient frontier but the decline is more pronounced at the higher end.

\section{[Insert Table 4 about here]}

\subsubsection{Increase in the Sharpe Ratio}

On each efficient set with and without FRE, Sharpe ratios are computed for 35 portfolios defined by return levels ranging from 9 to $17.5 \%$ in $.25 \%$ increments. ${ }^{1}$ Table 5 reports the Sharpe ratios of the efficient portfolios with and without FRE and shows an increase in the ratio as a result of the addition of FRE to a mixed asset portfolio. Consistent with the results on risk reduction and return enhancement, portfolios with returns around 12 to $15 \%$ benefit the most from the inclusion of FRE in mixed asset portfolios. These portfolios registered an increase in the Sharpe ratio of more than $100 \%$ relative to the corresponding portfolios without FRE.

\section{[Insert Table 5 about here]}

Tests of the statistical significance of differences in mean Sharpe ratios provide more robust evidence of diversification benefits. The mean Sharpe ratio becomes a summary measure of the excess return per unit of risk using the 35 equally spaced portfolios spanning the entire efficient set. The mean Sharpe ratios are compared using the parametric t-test and the non parametric Wilcoxon signed rank test. The bottom panel of Table 5 shows that the mean Sharpe ratio of efficient portfolios that include FRE is $71 \%$ higher than that without it, with both the parametric and nonparametric tests indicating a significant difference at the $1 \%$ level, strongly confirming the presence of diversification benefits. 


\subsection{The role of FRE in mixed asset portfolios}

Two points are evident from these results. First, the magnitude of the benefits from diversification with FRE, whether it is risk reduction or return enhancement, clearly depends on portfolio's position in the frontier. Second, the results also indicate that the gain in return is typically less than the risk reduction benefits, suggesting that FRE would best be used to reduce portfolio risk rather than to enhance return. This result is consistent with those of Lee and Stevenson (2006) and is not surprising given that FRE returns are negatively correlated with financial assets except for New Zealand equities.

Additional insight on the role of FRE in mixed asset portfolios can be deduced from an analysis of the assets that it replaces. Table 6 displays the detailed composition of the risk efficient portfolios. Panels A and B show the risk efficient portfolios without FRE and with FRE, respectively, while Panel C summarises the changes in the composition of the portfolios brought about by the introduction of FRE in the mix. Panel A shows that low risk portfolios in the efficient set without FRE are dominated by T-bills and bonds, with bonds taking on a more dominant role as one moves up the efficient frontier. At higher levels of return, equities become more dominant as bonds exit the portfolios. Not all equity markets are represented in the portfolios as NZ, Australia, US, HK and France dominate the equity markets. The UK and Singapore do not enter the efficient set, while Japan and Italy are kept at or below $5 \%$ of the mix and only in portfolios very close to the MVP. This is not surprising as these equity markets either have among the lowest reward-to-risk ratios as shown in Table 1 or are highly correlated with other equity

\footnotetext{
${ }^{1}$ The Sharpe ratios are computed using the average annual return of the NZ 90 day T-bills
} 
markets with superior reward-to-risk ratio as is the case of UK and the US. Panel C shows that the introduction of FRE in the choice set reduces the share of equities in the efficient portfolios for all return levels except those close to the maximum return portfolio (MRP). Again this is not surprising given the superior reward-torisk ratio of FRE relative to equities as shown in Table 1. Interestingly, the amount of T-bills in the efficient portfolios increase, with the introduction of FRE in the mix especially at the lower end of the efficient frontier. This seems to be at the expense of bonds, which has a lower reward-to-risk ratio than T-bills. Towards the median return levels of 12 to $14 \%$ the composition of both FRE and bonds in the efficient portfolios increase at the expense of equities. Again this could be explained by the inferior reward-to-risk ratio of equities relative to FRE and bonds. These results suggest that FRE acts as a risk-reducer at the middle to the higher end of the efficient frontier as it replaces the more volatile equities and has a dual role as a risk-reducer and a return-enhancer at the lower end of the frontier as it replaces equities and helps boost returns, as the lower earning T-bills replace bonds.

\section{[Insert Table 6 about here]}

\subsection{Robustness Tests}

It has been argued in the literature that since direct real estate data are appraisalrather than market-based, they are subject to considerable estimation errors (Michaud, 1989). Consequently it has been suggested that real estate form part of mixed asset portfolios due to the understatement of real estate risk and/or overstatement of returns (Michaud, 1989; Fisher et al.,1994; Corgel and de Roos,1999). It has also been suggested that inflation plays a role (Webb and

from1989-2005 as the proxy for the risk-free rate. Different proxies for the risk-free rate were also tried with the same results as those reported below. 
Rubens, 1987). In this section we test the robustness of FRE diversification benefits to changes in our original FRE risk and return estimates, as well as to changes in inflationary regimes. Table 7 shows the maximum risk reduction, maximum return enhancement, increase in mean Sharpe ratio, and maximum weight attained by FRE in the efficient frontier under the base case and various risk-return scenarios and two inflationary regimes.

\section{[Insert Table 7 about here]}

\subsubsection{Risk}

To address the issue of possible underestimation of FRE risk, we investigate the effect on the efficient set of a three-fold as well as a six-fold increase in the variance of FRE returns. Figure 4 displays the efficient sets with and without FRE using the original estimate of FRE risk. It also shows the efficient sets when FRE variance is tripled and sextupled. Figure 4 shows that the efficient sets with tripled and sextupled variance still dominate the set without FRE, indicating diversification benefits, albeit at a reduced level compared with the base case. Panel A of Table 7 quantifies these diversification benefits and shows that though the diversification benefits predictably fall as a result of the rise in the variance of FRE, they are still economically significant. The maximum risk reduction benefits fall from 54 to $36 \%$ (28\%) when the variance is tripled (sextupled), but these benefits are still equivalent to a $650(508)$ basis points reduction in the standard deviation of annual returns. Likewise, the maximum return enhancement benefits fall from 23 to $15 \%(11 \%)$ when the variance is tripled (sextupled) but this is still equivalent to an improvement in annual returns of 196 and 147 basis points, respectively. Table 7 also shows that though the proportion of FRE in risk efficient portfolios decreases as its variance is tripled (sextupled), it still attains a maximum weight of $50 \%$ 
$(38 \%)$ on the efficient frontier compared with $67 \%$ in the base case. Finally, Table 7 reports a 40 (27) percent improvement in the mean Sharpe ratio even as the variance of FRE is tripled (sextupled). Both the parametric t-test and the nonparametric Wilcoxon signed rank test indicate that these improvements are statistically significant at the $1 \%$ level. These results indicate that the diversification benefits of including FRE in efficient portfolios remain robust even if FRE return variance is tripled and sextupled from the original level.

\section{[Insert Figure 4 about here]}

\subsubsection{Returns}

Next, we investigate the effect of decreasing FRE's expected return from an initial value of $14.6 \%$ down to $13,12,11$ and 10 per cent. Figure 5 displays the efficient sets for the selected FRE return scenarios. It shows that all efficient sets with FRE dominate the efficient set without FRE. This clearly indicates diversification benefits in spite of a fall in FRE return. These benefits are again quantified in Panel A of Table 7. The maximum risk reduction benefits range from 14 to $43 \%$ or 86 to 501 basis points, and are attained by allocating 17 to $55 \%$ of the portfolio to FRE. The maximum return enhancement benefits range from 6 to $15 \%$ or 58 to 190 basis points per year and are likewise attained by allocating 15 to $57 \%$ of the portfolio to FRE. Table 7 also shows that despite a fall in FRE returns, FRE still enters the efficient portfolios at a maximum weight of 40-63\%. We also report significant improvements in the mean Sharpe ratio ranging from 8 to $44 \%$. These improvements are statistically significant at the $1 \%$ level using both the parametric t-test and the non-parametric signed rank test. These results show that diversification benefits are robust under different FRE return scenarios. 
Panel A of Table 7 shows further that diversification benefits are more sensitive to a fall the FRE return than to a rise in FRE variance. For example, the effect on maximum risk reduction benefits of a $600 \%$ rise in FRE variance is the same as an $11 \%$ drop in FRE returns from 14.6 to $13 \%$. In the same way, the effect on the maximum return enhancement benefits of a 300\% rise in FRE variance is almost the same as an $11 \%$ drop in FRE returns from 14.6 to $13 \%$. Futhermore, the effect of a $300 \%$ increase in FRE variance results in a $46 \%$ fall in the mean Sharpe ratio from .74 to .40 , while an $11 \%$ decline in FRE returns already results to a $40 \%$ fall in the same from .74 to .44 . This suggests that errors in the estimation of FRE returns are more critical than errors in the estimation of the variance of returns.

\subsubsection{De-smoothed FRE returns}

To further address the issue of understatement of the volatility of real estate returns when using appraisal-based data as we have here, we de-smoothed the FRE return series using Geltner's (1993) method. Geltner (1993) proposed the following reverse filter to recover the underlying property series from appraisal-based data:

$$
\mathrm{R}_{\mathrm{t}}^{\mathrm{u}}=\left[\mathrm{R}_{\mathrm{t}}^{*}-(1-\alpha) \mathrm{R}_{\mathrm{t}-1}{ }^{\mathrm{u}}\right] / \alpha
$$

where $\mathrm{R}_{\mathrm{t}}{ }^{\mathrm{u}}$ is the unobserved underlying return, $\mathrm{R}_{\mathrm{t}}{ }^{*}$ is the reported appraisal-based return, and $\alpha$ is a de-smoothing parameter with values between 0 and 1 . A value for $\alpha$ of 1 implies no smoothing in the appraisal-based data. Following Geltner (1993), we de-smooth the FRE series using a value of 0.40 for $\alpha$ as well as a lower bound of 0.33 , and an upper bound of 0.50 .

Table 8 shows the risk and return measures of the appraisal-based FRE series as well as the desmoothed series. It also shows FRE's correlation coefficients 
with the various financial assets. The de-smoothed series exhibit both higher return and volatility compared with the appraisal-based data. In particular, the variance increased approximately nine-fold, six-fold, and four-fold as we used $\alpha$ values of $0.33,0.40$, and 0.50 , respectively. Therefore using $\alpha$ values of 0.40 and 0.50 roughly corresponds to the earlier FRE risk scenarios that assume a six- and threefold increase in variance, respectively.

The correlation coefficient of the de-smoothed FRE with the financial assets is less negative for US, UK, and Hong Kong while it turned from negative to positive for France, Italy, and Japan, when compared with the correlation coefficient using appraisal-based data. The correlation coefficient remained almost the same for NZ bonds, Australia, and Singapore, and while it became more negative for NZ T-bills. On the whole, de-smoothing appears to have increased the volatility of the FRE return series and generally increased its correlation with the financial assets implying lower diversification benefits relative to that provided by the appraisal-based FRE series.

Panel B of Table 7 shows the benefits of diversification using the desmoothed series. As expected, the results obtained when $\alpha$ was set to 0.40 and 0.50 are very similar to the results of the FRE risk scenarios where variance was increased six- and three-fold, respectively. Risk reduction was in the order of 500 to 600 basis points with FRE attaining a maximum weight of 41 to $48 \%$ on the efficient frontier. The mean Sharpe ratio increased by 30 to $39 \%$ relative to the base case without FRE and the increase was significant at the $1 \%$ level using both the parametric and non-parametric tests. Using an $\alpha$ equal to 0.33 amounted to increasing the FRE return variance nine-fold. Though the maximum risk reduction and return enhancement are lower, FRE still attains a maximum weight of 34\% on 
the efficient frontier. Therefore, even with the de-smoothed series the benefits from diversification with FRE are still evident.

\subsubsection{Inflation}

We also test if inflation plays a role in making FRE an attractive asset for diversification. Our results strongly reject this suggestion given that $1989-2005$ is a relatively low inflation period in New Zealand with an average annual inflation rate of $2.5 \%$, yet FRE is a significant component of risk efficient portfolios. As a further test we use a different data set to compare two periods with different inflationary environments. We use only FRE and equity markets as we do not have complete data on NZ T-bills and bonds. We consider the period 1974-88 with an average annual inflation rate of $13.1 \%$ in New Zealand, and 1989-2003 with an average inflation rate of $2.4 \%$. Again we reject the inflation explanation as our results in panel $\mathrm{C}$ of Table 7 show that in the period of high inflation, FRE entered risk efficient portfolios at a maximum of $61 \%$ while in the period of low inflation FRE entered risk efficient portfolios at and even higher proportion of 65\%. Likewise, we report statistically significant improvements in the mean Sharpe ratio when FRE is included in the mixed asset portfolio, but the magnitude of the improvement is higher in the low inflation period (1989-2003) rejecting the inflation explanation. The mean Sharpe ratio increased by $60 \%$ from 0.326 to 0.520 in the low inflation period while it only increased $38 \%$ from .589 to .813 in the high inflation period. These differences in Sharpe ratio are statistically significant at the $1 \%$ level in both parametric and non-parametric tests.

Overall, in all risk-return scenarios as well as in the two inflationary regimes considered in this study, FRE enters the risk efficient portfolios at an 
economically significant level ranging from 15 to $65 \%$ while retaining significant risk reduction and return enhancement benefits.

\subsection{Consistency}

Finally, we test if FRE is a consistent part of the efficient set using an adaptation of Lee and Stevenson's (2006) procedure. We generate efficient sets for 5- and 10year rolling periods beginning in 1989 and ending in 2005. This test is meant to address the observation in the literature of time-varying equity market correlations (see for example, Solnik, et al., 1996; Goetzman et al., 2002; Meyer and Rose, 2003; Kearney and Lucey, 2006).

The 5-year rolling periods are defined as returns from 1989 to 1993, 1990 to 1994, and so on until 2001 to 2005 . The 10 -year rolling periods are similarly defined as returns from 1989 to 1998, 1990 to 1999, and so on until 1996 to 2005. There are a total of thirteen 5-year rolling periods and eight 10-year rolling periods. The efficient frontier generated for each rolling period is defined by ten portfolios that are equally spaced according to expected return, including the MVP (Portfolio 1) and the MRP (Portfolio 10).

Table 9 shows that FRE is a consistent component of the efficient set under both the 5- and 10-year rolling periods. In the 5-year rolling periods, FRE achieved a positive allocation in the efficient portfolios more than $75 \%$ of the time at the lower end of the frontier (Portfolios 1 to 5). This number declines as we move up the frontier towards the MRP. The mean allocation of FRE in the ten portfolios ranged from 15 to $35 \%$. It has been suggested in the literature that allocating $20 \%$ of a mixed asset portfolio to real estate is a viable strategy (e.g., Folger, 1984; Sweeney, 1988). Table 9 shows that the mean FRE allocation in the efficient 
portfolios exceeded this level, $69-77 \%$ of the time in the middle portfolios (Portfolios 4 to 6) attaining an average allocation ranging from 33 to $35 \%$.

FRE is an even more consistent part of the efficient set in the 10-year rolling periods. FRE attained a positive allocation $100 \%$ of the time in eight of the ten efficient portfolios. FRE also exceeded the $20 \%$ allocation $100 \%$ of the time in the middle portfolios (Portfolios 4 to 6 ) achieving a mean allocation of 38 to $44 \%$ with diminishing allocation as we move in either direction towards the upper and lower ends of the frontier.

Based on this evidence we conclude that FRE can be expected to be a consistent part of the efficient set.

\section{Conclusion}

This study investigated the benefits of further diversifying a mixed portfolio of international financial assets with farm real estate (FRE). The results show that given the predominantly negative correlation between FRE and financial assets, the risk-return tradeoffs of such portfolios can be improved significantly. The diversification benefits measured in terms of risk reduction, return enhancement, and improvement in the Sharpe ratio are robust under a number of FRE risk-return scenarios as well as under high and low inflationary periods. Using 5- and 10-year rolling periods, FRE was found to be a consistent part of efficient portfolios.

The results also show that risk reduction benefits of diversifying with FRE are larger than the risk enhancement benefits. This suggests a role for FRE in mixed asset portfolios that typify more of a risk-reducer rather than a return-enhancer. The practical implication of our findings is that investors can significantly enhance their portfolio risk-return tradeoffs, particularly by reducing risk, through diversification 
into FRE. FRE therefore appears to deserve more serious consideration by investment practitioners than it has been accorded in the past. We conjecture that such is the result of limited avenues by which they can invest in FRE. Therefore, it is also important to explore ways of making it easier for investment practitioners to invest in FRE probably through the wider introduction and development of unit trusts investing in direct FRE. 


\section{References}

Barry, P.J. (1980). Capital asset pricing and farm real estate, American Journal of Agricultural Economics 62, 549-553.

Corgel, J.B., and deRoos, J.A. (1999), Recovery of Real Estate Returns for Portfolio allocation, Journal of Real Estate Finance and Economics, 18, 279-296.

Eves, C. and Newell, G. (2007), The role of US Farmland in Real Estate Investment Portfolios. Journal of Real Estate Portfolio Management, 14, 317-327.

Fisher, J.D., Geltner, D.M., and Webb, R.B. (1994) Value Indices of Commercial Real Estate: A Comparison of Index Construction Methods, Journal of Real Estate Finance and Economics, 9, 137-164.

Fletcher, J. and Marshall, A. (2005). An empirical examination of the benefits of international diversification. Journal of International Financial Markets Institutions and Money, 15, 455-468.

Folger, H.R. (1984) 20\% in real estate: Can theory justify it? The Journal of Portfolio Management, Winter, 6-13.

Geltner, D. (1993) Estimating market values from appraised values without assuming an efficient market. Journal of Real Estate Research, 8, 325-45.

Goetzmann, W.N., Li, L., and Rouwenhorst, K.G. (2002). Long-term global market correlations. Working Paper National Bureau of Economic Research.

Haugen, R. (1990). Modern Investment Theory, 2nd ed., Prentice-Hall Inc., New Jersey.

Harvey, C.R. (1991). The world price of covariance risk. Journal of Finance 46, 111-158. 
Kaplan, H.M. (1985). Farmland as a portfolio investment. The Journal of Portfolio Management 11, 73-79.

Kearney, C., and B.M. Lucey (2004). International equity market integration: Theory, evidence and implications, International Review of Financial Analysis 13, 571-583.

Lee, S. and Stevenson, S. (2006). Real estate in the mixed-asset portfolio: the question of consistency, Journal of Property Investment and Finance 24, 123-135.

Levy, H. and Sarnat, M. (1970). International diversification of investment portfolios. American Economic Review 60, 668-675.

Li, K., Sarkar, A., and Wang, Z. (2003). Diversification benefits of emerging markets subject to portfolio constraints. Journal of Empirical Finance 10, $57-80$.

Lins, D., Kowalski, A., and Hoffman, C. (1992). Institutional investment diversification: foreign stocks vs. U.S. farmland, Proceedings of Regional Research Committee NC-161, Department of Agricultural Economics, Kansas State University, Manhattan, Kansas.

Lintner, J. (1965). The valuation of risky assets and selection of risk investments in stock portfolios and capital budgets, Review of Economic Statistics 47, 1337.

Markowitz, H.M. (1952). Portfolio selection, Journal of Finance, 12, 77-91.

Meyer, T.O., and Rose, L.C. (2003). The persistence of international diversification benefits before and during the Asian crisis. Global Finance Journal $14217-$ 242. 
Michaud, R.O. (1989). The Markowitz optimization enigma: is 'optimised' optimal? Financial Analysts Journal January/February 31-42.

Moss, C.B., Featherstone, M., and Baker, T.G. (1987). Agricultural assets in an efficient multi-period investment portfolio, Agricultural Finance Review 47, $82-94$.

Nartea, G. and Eves, C. (2008). Diversification benefits from New Zealand real estate. Pacific Rim Property Research Journal 14:1, 27-43.

Nartea, G.V., and Dhungana, B.R. (1998). Diversifiable and nondiversifiable risk in New Zealand dairy farming, Proceedings of the NZ Farm Management Society Annual Conference; 18-20 Nov 1998, Waikato University, Hamilton, pp.172-182.

Nartea, G.V., and Pellegrino, J.M. (1999). Off-farm investment in financial assets as a risk response for New Zealand sheep and beef farms, Research Report 99/07, Farm and Horticultural Management Group, Division of Applied Management and Computing, Lincoln University.

Nartea, G. and Webster, P. (2008). Should farmers invest in financial assets as a risk management strategy? Some evidence from New Zealand. Australian Journal of Agricultural and Resource Economics 52, 183-202.

New Zealand Meat and Wool Board Economic Service (various dates). The New Zealand Sheep and Beef Farm Survey, Wellington. Selected issues.

Phengpis, C. and Swanson, P.E. (2004). Increasing input information and realistically measuring potential diversification gains from international portfolio investments. Global Finance Journal 15, 197-217.

Painter, M.J. (2000). Should Saskatchewan farmland be part of your investment portfolio? Canadian Journal of Agricultural Economics 48, 39-50. 
Sharpe, W.F. (1966). Mutual fund performance, Journal of Business 39, 119-138.

Seiler, M, Webb, J.R., and Myer, F.C. N. (1999). Diversification issues in real estate investment. Journal of Real Estate Literature 7, 163-179.

Solnik, B., Boucrelle, C., and Le Fur, Y. (1996). International market correlation and volatility. Financial Analysts Journal 52, 17-34.

Sweeney, F. (1988) 20\% in Property - a Viable Strategy? Estates Gazette, 13 February, 26-28.

Valuation New Zealand. Rural Property Sales Statistics. Wellington. Selected issues.

Webb, J.R., and Rubens, J.H (1987). How much in real estate? A surprising answer, The Journal of Portfolio Management, Spring, 10-14.

Young, R. and Barry, P.J. (1987). Holding financial assets as a risk response: a portfolio analysis of Illinois grain farms, North Central Journal of Agricultural Economics 9, 77-84. 
Table 1. Risk and Return Measures for Farm real estate and Financial Assets, 1989-2005

\begin{tabular}{lcccc}
\hline & $\begin{array}{c}\text { Mean annual } \\
\text { rate of return }\end{array}$ & $\begin{array}{c}\text { Standard } \\
\text { deviation } \\
(\%)(\text { Rank })\end{array}$ & $\begin{array}{c}\text { Coefficient of } \\
\text { variation } \\
(\%)\end{array}$ & $\begin{array}{c}\text { Reward-to- } \\
\text { risk ratio } \\
\text { (Rank) }\end{array}$ \\
\hline Farmland & & & & \\
$\quad$ Production return & 2.41 & 1.28 & 0.53 & \\
$\quad$ Capital gain & 12.14 & 11.12 & 0.92 & \\
$\quad$ Total return & $14.58(3)$ & 10.99 & 0.75 & $1.33(3)$ \\
90 day T-bills & $8.32(11)$ & 3.19 & 0.38 & $2.63(1)$ \\
Bonds & $9.56(10)$ & 4.98 & 0.52 & $1.92(2)$ \\
New Zealand & $11.52(8)$ & 13.33 & 1.16 & $0.86(5)$ \\
Australia & $12.24(6)$ & 12.29 & 1.00 & $1.00(4)$ \\
US & $14.42(4)$ & 23.85 & 1.65 & $0.61(6)$ \\
UK & $12.94(5)$ & 22.59 & 1.75 & $0.57(7)$ \\
Japan & $1.96(12)$ & 27.76 & 14.20 & $0.07(12)$ \\
Hong Kong & $17.56(1)$ & 31.40 & 1.79 & $0.56(8)$ \\
Singapore & $10.93(9)$ & 29.87 & 2.73 & $0.37(10)$ \\
France & $15.92(2)$ & 30.52 & 1.92 & $0.52(9)$ \\
Italy & $11.70(7)$ & 34.32 & 2.93 & $0.34(11)$ \\
\hline
\end{tabular}

${ }^{a}$ All figures in nominal terms. 
Table 2. Correlation of Farm Real Estate and Financial Asset Returns, 1989-2005

\begin{tabular}{|c|c|c|c|c|c|c|c|c|c|c|c|c|}
\hline & $\begin{array}{l}\text { Farm } \\
\text { real } \\
\text { estate }\end{array}$ & $\begin{array}{l}90 \text { day } \\
\text { T-bills }\end{array}$ & Bonds & $\begin{array}{l}\text { New } \\
\text { Zealand }\end{array}$ & Australia & U.S. & U.K. & Japan & $\begin{array}{l}\text { Hong } \\
\text { Kong }\end{array}$ & Singapore & France & Italy \\
\hline $\begin{array}{l}\text { Farm real } \\
\text { estate } \\
90 \text { day T- }\end{array}$ & 1.00 & -0.18 & -0.29 & 0.29 & -0.26 & -0.44 & -0.23 & -0.05 & -0.16 & -0.18 & -0.12 & -0.08 \\
\hline bills & & 1.00 & 0.72 & -0.22 & 0.17 & 0.41 & 0.37 & -0.16 & 0.11 & 0.15 & 0.28 & 0.18 \\
\hline $\begin{array}{l}\text { Bonds } \\
\text { New }\end{array}$ & & & 1.00 & -0.13 & 0.01 & 0.19 & 0.16 & -0.29 & 0.23 & 0.00 & 0.01 & -0.29 \\
\hline Zealand & & & & 1.00 & 0.22 & -0.17 & -0.14 & 0.29 & 0.33 & 0.42 & -0.11 & -0.18 \\
\hline Australia & & & & & 1.00 & 0.44 & 0.43 & 0.32 & 0.60 & 0.58 & 0.37 & 0.32 \\
\hline US & & & & & & 1.00 & 0.90 & 0.28 & 0.18 & 0.13 & 0.83 & 0.75 \\
\hline UK & & & & & & & 1.00 & 0.05 & 0.21 & -0.01 & 0.91 & 0.81 \\
\hline Hong & & & & & & & & 1.00 & 0.32 & 0.55 & 0.21 & 0.18 \\
\hline Kong & & & & & & & & & 1.00 & 0.50 & 0.16 & -0.13 \\
\hline Singapore & & & & & & & & & & 1.00 & 0.07 & -0.03 \\
\hline France & & & & & & & & & & & 1.00 & 0.89 \\
\hline Italy & & & & & & & & & & & & 1.00 \\
\hline
\end{tabular}


Table 3. Risk Efficient Portfolios (Risk reduction)

\begin{tabular}{|c|c|c|c|c|c|c|c|c|c|c|c|}
\hline \multicolumn{12}{|c|}{ Portfolio } \\
\hline & $1^{\mathrm{a}}$ & 2 & 3 & 4 & 5 & 6 & 7 & 8 & 9 & 10 & $11^{\mathrm{b}}$ \\
\hline \multicolumn{12}{|l|}{ Assets } \\
\hline 90 day T-bills & 90.1 & 70.9 & 12.2 & 0.0 & 0.0 & 0.0 & 0.0 & 0.0 & 0.0 & 0.0 & 0.0 \\
\hline Bonds & 0.0 & 13.8 & 60.6 & 54.5 & 36.5 & 18.5 & 0.5 & 0.0 & 0.0 & 0.0 & 0.0 \\
\hline Equities & 9.9 & 15.3 & 27.2 & 45.5 & 63.5 & 81.5 & 95.5 & 100.0 & 100.0 & 100.0 & 100.0 \\
\hline Expected return $(\%)$ & 8.5 & 9.0 & 10.0 & 11.0 & 12.0 & 13.0 & 14.0 & 15.0 & 16.0 & 17.0 & 17.6 \\
\hline Standard deviation $(\%)$ & 2.9 & 3.0 & 3.8 & 5.5 & 8.0 & 10.7 & 13.6 & 16.8 & 20.5 & 24.6 & 31.4 \\
\hline \multicolumn{12}{|c|}{ Panel B. Efficient portfolios with Farm real estate } \\
\hline \multicolumn{12}{|c|}{ Portfolio } \\
\hline & & $1^{\mathrm{a}}$ & 2 & 3 & 4 & 5 & 6 & 7 & 8 & 9 & $10^{\mathrm{b}}$ \\
\hline \multicolumn{12}{|l|}{ Assets } \\
\hline Farm real estate & & 9.4 & 16.8 & 24.2 & 35.1 & 47.3 & 59.1 & 66.7 & 43.6 & 6.9 & 0.0 \\
\hline 90 day T-bills & & 79.9 & 46.1 & 16.7 & 0.0 & 0.0 & 0.0 & 0.0 & 0.0 & 0.0 & 0.0 \\
\hline Bonds & & 3.1 & 25.5 & 43.4 & 44.8 & 28.6 & 12.5 & 0.0 & 0.0 & 0.0 & 0.0 \\
\hline Equities & & 7.6 & 11.6 & 15.7 & 20.1 & 24.1 & 28.4 & 33.3 & 56.4 & 93.1 & 100.0 \\
\hline Expected return $(\%)$ & & 9.0 & 10.0 & 11.0 & 12.0 & 13.0 & 14.0 & 15.0 & 16.0 & 17.0 & 17.6 \\
\hline Standard deviation (\%) & & 2.7 & 2.9 & 3.3 & 3.9 & 5.0 & 6.3 & 8.0 & 14.2 & 24.3 & 31.4 \\
\hline Reduction in risk $(\%)^{\mathrm{c}}$ & & 11.1 & 25.3 & 40.1 & 51.2 & 53.8 & 53.7 & 52.7 & 30.4 & 1.4 & 0.0 \\
\hline Reduction in risk (basis points) $^{\mathrm{d}}$ & & 33.5 & 96.6 & 219.5 & 408.2 & 578.5 & 733.0 & 886.4 & 623.1 & 33.6 & 0.0 \\
\hline
\end{tabular}

\footnotetext{
${ }^{\mathrm{a}}$ Global Minimum Variance Portfolio (MVP)

${ }^{\mathrm{b}}$ Maximum Expected Return Portfolio (MRP)

${ }^{c}$ percentage increase in return relative to the corresponding portfolio with the same expected return in the efficient set without farm real estate

$\mathrm{d}$ basis point increase in return relative to the corresponding portfolio with the same expected return in the efficient set without farm real estate
} 
Table 4. Risk Efficient Portfolios (Return enhancement)

\begin{tabular}{|c|c|c|c|c|c|c|c|c|c|c|}
\hline \multicolumn{11}{|c|}{ Panel A. Efficient portfolios without Farm real estate } \\
\hline & \multicolumn{10}{|c|}{ Portfolio } \\
\hline & 1 & 2 & 3 & 4 & 5 & 6 & 7 & 8 & 9 & 10 \\
\hline \multicolumn{11}{|l|}{ Assets } \\
\hline 90 day T-bills & 70.9 & 0.0 & 0.0 & 0.0 & 0.0 & 0.0 & 0.0 & 0.0 & 0.0 & 0.0 \\
\hline Bonds & 13.8 & 50.4 & 29.7 & 10.4 & 0.0 & 0.0 & 0.0 & 0.0 & 0.0 & 0.0 \\
\hline Equities & 15.3 & 49.6 & 70.3 & 89.6 & 100.0 & 100.0 & 100.0 & 100.0 & 100.0 & 100.0 \\
\hline Expected return $(\%)$ & 9.0 & 11.2 & 12.4 & 13.5 & 14.5 & 15.3 & 16.1 & 16.9 & 17.3 & 17.5 \\
\hline Standard deviation $(\%)$ & 3.0 & 6.0 & 9.0 & 12.0 & 15.0 & 18.0 & 21.0 & 24.0 & 27.0 & 30.0 \\
\hline \multicolumn{11}{|c|}{ Panel B. Efficient portfolios with Farm real estate } \\
\hline & \multicolumn{10}{|c|}{ Portfolio } \\
\hline & 1 & 2 & 3 & 4 & 5 & 6 & 7 & 8 & 9 & 10 \\
\hline \multicolumn{11}{|l|}{ Assets } \\
\hline Farm real estate & 18.9 & 56.3 & 63.9 & 53.5 & 40.7 & 28.9 & 18.3 & 7.6 & 0.0 & 0.0 \\
\hline 90 day T-bills & 35.3 & 0.0 & 0.0 & 0.0 & 0.0 & 0.0 & 0.0 & 0.0 & 0.0 & 0.0 \\
\hline Bonds & 32.9 & 16.4 & 0.0 & 0.0 & 0.0 & 0.0 & 0.0 & 0.0 & 0.0 & 0.0 \\
\hline Equities & 12.9 & 27.4 & 36.1 & 46.5 & 59.3 & 71.1 & 81.7 & 92.4 & 100.0 & 100.0 \\
\hline Expected return (\%) & 10.3 & 13.8 & 15.2 & 15.7 & 16.1 & 16.4 & 16.7 & 17.0 & 17.3 & 17.5 \\
\hline Standard deviation (\%) & 3.0 & 6.0 & 9.0 & 12.0 & 15.0 & 18.0 & 21.0 & 24.0 & 27.0 & 30.0 \\
\hline Increase in return $(\%)^{\mathrm{a}}$ & 14.4 & 22.5 & 23.0 & 17.0 & 11.3 & 7.0 & 3.4 & 0.5 & 0.0 & 0.0 \\
\hline Increase in return (basis points) ${ }^{b}$ & 130.0 & 252.9 & 285.0 & 228.0 & 163.0 & 107.0 & 55.0 & 8.0 & 0.0 & 0.0 \\
\hline
\end{tabular}

${ }^{a}$ percentage increase in return relative to the corresponding portfolio with the same risk (standard deviation) in the efficient set without farm real estate
$\mathrm{b}$ basis point increase in return relative to the corresponding portfolio with the same risk (standard deviation) in the efficient set without farm real estate 
Table 5. Sharpe Ratios for Efficient Sets With and Without Farm Real Estate

\begin{tabular}{|c|c|c|c|}
\hline \multirow{2}{*}{$\begin{array}{l}\text { Return level } \\
(\%)\end{array}$} & \multicolumn{2}{|c|}{ Sharpe Ratio } & \multirow{2}{*}{$\begin{array}{l}\% \text { Increase in } \\
\text { Sharpe ratio }\end{array}$} \\
\hline & Without FRE & With FRE & \\
\hline 9.00 & 0.23 & 0.25 & 12.27 \\
\hline 9.25 & 0.29 & 0.34 & 17.41 \\
\hline 9.50 & 0.35 & 0.43 & 23.08 \\
\hline 9.75 & 0.40 & 0.51 & 28.78 \\
\hline 10.00 & 0.44 & 0.58 & 31.03 \\
\hline 10.25 & 0.47 & 0.66 & 39.12 \\
\hline 10.50 & 0.48 & 0.72 & 48.03 \\
\hline 10.75 & 0.49 & 0.77 & 56.65 \\
\hline 11.00 & 0.49 & 0.81 & 66.67 \\
\hline 11.25 & 0.48 & 0.86 & 77.42 \\
\hline 11.50 & 0.48 & 0.90 & 87.61 \\
\hline 11.75 & 0.47 & 0.93 & 97.57 \\
\hline 12.00 & 0.46 & 0.94 & 105.13 \\
\hline 12.25 & 0.45 & 0.95 & 109.71 \\
\hline 12.50 & 0.45 & 0.96 & 113.73 \\
\hline 12.75 & 0.44 & 0.95 & 115.45 \\
\hline 13.00 & 0.44 & 0.94 & 114.00 \\
\hline 13.25 & 0.43 & 0.93 & 117.05 \\
\hline 13.50 & 0.43 & 0.92 & 117.11 \\
\hline 13.75 & 0.42 & 0.91 & 116.61 \\
\hline 14.00 & 0.42 & 0.90 & 115.87 \\
\hline 14.25 & 0.41 & 0.89 & 115.59 \\
\hline 14.50 & 0.41 & 0.88 & 115.34 \\
\hline 14.75 & 0.40 & 0.87 & 115.52 \\
\hline 15.00 & 0.40 & 0.84 & 110.00 \\
\hline 15.25 & 0.39 & 0.76 & 94.29 \\
\hline 15.50 & 0.39 & 0.68 & 77.14 \\
\hline 15.75 & 0.38 & 0.61 & 60.48 \\
\hline 16.00 & 0.37 & 0.54 & 44.37 \\
\hline 16.25 & 0.37 & 0.48 & 29.47 \\
\hline 16.50 & 0.37 & 0.43 & 17.70 \\
\hline 16.75 & 0.36 & 0.39 & 8.23 \\
\hline 17.00 & 0.35 & 0.36 & 1.23 \\
\hline 17.25 & 0.33 & 0.33 & 0.00 \\
\hline 17.50 & 0.30 & 0.30 & 0.00 \\
\hline Mean Sharpe ratio & 0.41 & 0.70 & \\
\hline Std dev. of Sharpe ratio & 0.06 & 0.23 & \\
\hline t-stat & & $9.156 * *$ & \\
\hline Wilcoxon signed rank & & $528 * *$ & \\
\hline
\end{tabular}

FRE, farm real estate

$\mathrm{t}$ stat (signed rank) is the parametric (nonparametric) test statistic in comparing the difference in the mean Sharpe ratios with and without FRE; ** Indicates significance at the .01 level 
Table 6. Composition of Risk Efficient Portfolios

Panel A. Risk Efficient Portfolios without Farm Real Estate

\begin{tabular}{|c|c|c|c|c|c|c|c|c|c|c|c|}
\hline & \multicolumn{11}{|c|}{ Portfolio } \\
\hline & $1^{\mathrm{a}}$ & 2 & 3 & 4 & 5 & 6 & 7 & 8 & 9 & 10 & $11^{\mathrm{b}}$ \\
\hline \multicolumn{12}{|l|}{ Composition (\%) } \\
\hline 90 day T-bills & 90.1 & 70.9 & 12.2 & 0.0 & 0.0 & 0.0 & 0.0 & 0.0 & 0.0 & 0.0 & 0.0 \\
\hline Bonds & 0.0 & 13.8 & 60.6 & 54.5 & 36.5 & 18.5 & 0.5 & 0.0 & 0.0 & 0.0 & 0.0 \\
\hline New Zealand & 8.4 & 11.8 & 15.8 & 21.0 & 27.4 & 33.8 & 40.1 & 28.7 & 12.9 & 0.0 & 0.0 \\
\hline Australia & 0.0 & 2.5 & 6.9 & 14.9 & 11.7 & 8.6 & 5.4 & 0.0 & 0.0 & 0.0 & 0.0 \\
\hline US & 0.0 & 0.0 & 0.0 & 0.3 & 6.3 & 12.4 & 18.4 & 14.7 & 8.2 & 0.0 & 0.0 \\
\hline UK & 0.0 & 0.0 & 0.0 & 0.0 & 0.0 & 0.0 & 0.0 & 0.0 & 0.0 & 0.0 & 0.0 \\
\hline Japan & 1.5 & 0.0 & 0.0 & 0.0 & 0.0 & 0.0 & 0.0 & 0.0 & 0.0 & 0.0 & 0.0 \\
\hline Hong Kong & 0.0 & 0.0 & 0.0 & 1.4 & 8.2 & 14.9 & 21.7 & 34.3 & 47.0 & 65.9 & 100.0 \\
\hline Singapore & 0.0 & 0.0 & 0.0 & 0.0 & 0.0 & 0.0 & 0.0 & 0.0 & 0.0 & 0.0 & 0.0 \\
\hline France & 0.0 & 0.0 & 0.0 & 7.9 & 9.9 & 11.8 & 13.8 & 22.3 & 31.9 & 34.1 & 0.0 \\
\hline Italy & 0.0 & 1.1 & 4.5 & 0.0 & 0.0 & 0.0 & 0.0 & 0.0 & 0.0 & 0.0 & 0.0 \\
\hline Expected return $(\%)$ & 8.5 & 9.0 & 10.0 & 11.0 & 12.0 & 13.0 & 14.0 & 15.0 & 16.0 & 17.0 & 17.6 \\
\hline Standard deviation (\%) & 2.9 & 3.0 & 3.8 & 5.5 & 8.0 & 10.7 & 13.6 & 16.8 & 20.5 & 24.6 & 31.4 \\
\hline
\end{tabular}


Portfolio

$1^{\mathrm{a}}$

$\begin{array}{lll}2 & 3\end{array}$

5

6

7

8

9

$10^{\mathrm{b}}$

Composition (\%)

\begin{tabular}{|c|c|c|c|c|c|c|c|c|c|c|}
\hline Farm real estate & 9.4 & 16.8 & 24.2 & 35.1 & 47.3 & 59.1 & 66.7 & 43.6 & 6.9 & 0.0 \\
\hline 90 day T-bills & 79.9 & 46.1 & 16.7 & 0.0 & 0.0 & 0.0 & 0.0 & 0.0 & 0.0 & 0.0 \\
\hline Bonds & 3.1 & 25.5 & 43.4 & 44.8 & 28.6 & 12.5 & 0.0 & 0.0 & 0.0 & 0.0 \\
\hline Australia & 0.8 & 6.0 & 9.8 & 12.7 & 9.4 & 5.4 & 0.0 & 0.0 & 0.0 & 0.0 \\
\hline US & 0.0 & 0.0 & 1.8 & 6.6 & 11.4 & 16.4 & 18.2 & 0.0 & 0.0 & 0.0 \\
\hline UK & 0.0 & 0.0 & 0.0 & 0.0 & 0.0 & 0.0 & 0.0 & 0.0 & 0.0 & 0.0 \\
\hline Japan & 2.0 & 1.1 & 0.0 & 0.0 & 0.0 & 0.0 & 0.0 & 0.0 & 0.0 & 0.0 \\
\hline Hong Kong & 0.0 & 0.0 & 0.0 & 0.0 & 3.2 & 6.6 & 15.1 & 40.5 & 71.5 & 100.0 \\
\hline Singapore & 0.0 & 0.0 & 0.0 & 0.0 & 0.0 & 0.0 & 0.0 & 0.0 & 0.0 & 0.0 \\
\hline France & 0.0 & 0.0 & 0.0 & 0.0 & 0.0 & 0.0 & 0.0 & 15.9 & 21.6 & 0.0 \\
\hline Italy & 0.0 & 1.0 & 1.3 & 0.0 & 0.0 & 0.0 & 0.0 & 0.0 & 0.0 & 0.0 \\
\hline Expected return $(\%)$ & 9.0 & 10.0 & 11.0 & 12.0 & 13.0 & 14.0 & 15.0 & 16.0 & 17.0 & 17.6 \\
\hline tandard deviation $(\%)$ & 2.7 & 2.9 & 3.3 & 3.9 & 5.0 & 6.3 & 8.0 & 14.2 & 24.3 & 31.4 \\
\hline
\end{tabular}


Panel C. Change in the Composition of Risk Efficient Portfolios with the Introduction of FRE

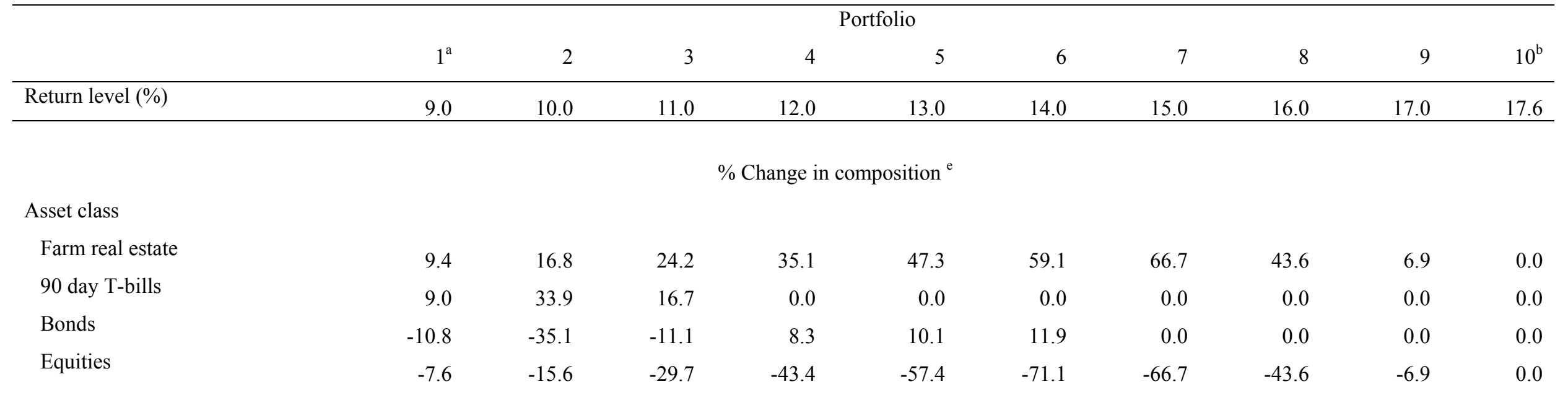

${ }^{\mathrm{a}}$ Global Minimum Variance Portfolio (MVP)

${ }^{\mathrm{b}}$ Maximum Expected Return Portfolio (MRP) 


\begin{tabular}{|c|c|c|c|c|c|c|c|c|c|c|c|}
\hline \multirow[b]{3}{*}{ Panel A } & \multicolumn{3}{|c|}{ Maximum risk reduction } & \multicolumn{3}{|c|}{$\begin{array}{l}\text { Maximum return } \\
\text { enhancement }\end{array}$} & \multirow{3}{*}{$\begin{array}{l}\text { Maximum } \\
\text { weight on } \\
\text { frontier } \\
\%\end{array}$} & \multirow{3}{*}{$\begin{array}{l}\text { Mean } \\
\text { Sharpe } \\
\text { Ratio }\end{array}$} & \multirow{3}{*}{$\begin{array}{c}\text { Increase in } \\
\text { Mean Sharpe } \\
\text { Ratio }^{\text {a }} \\
\%\end{array}$} & \multirow[t]{3}{*}{ t-stat } & \multirow[t]{3}{*}{$\begin{array}{l}\text { Signed } \\
\text { rank }\end{array}$} \\
\hline & $\%$ & $\begin{array}{l}\text { basis } \\
\text { points }\end{array}$ & $\begin{array}{c}\text { FRE } \\
\text { Weight }\end{array}$ & $\%$ & $\begin{array}{l}\text { basis } \\
\text { points }\end{array}$ & $\begin{array}{c}\text { FRE } \\
\text { Weight }\end{array}$ & & & & & \\
\hline & & & & & & & & & & & \\
\hline Base Case without FRE (1989-2005) & - & - & - & - & - & - & 0 & 0.407 & - & - & - \\
\hline Base Case with FRE (1989-2005) & 54 & 886 & 67 & 23 & 285 & 64 & 67 & 0.701 & 72 & $9.156 * *$ & $0.000 * *$ \\
\hline \multicolumn{12}{|l|}{ FRE risk scenarios } \\
\hline $3 \mathrm{x}$ variance & 36 & 650 & 48 & 15 & 196 & 47 & 50 & 0.564 & 39 & $9.845 * *$ & $561 * *$ \\
\hline $6 \mathrm{x}$ variance & 28 & 508 & 38 & 11 & 147 & 37 & 38 & 0.514 & 26 & $10.438 * *$ & $528 * *$ \\
\hline \multicolumn{12}{|l|}{ FRE return scenarios } \\
\hline 13 per cent & 43 & 501 & 54 & 15 & 190 & 57 & 63 & 0.586 & 44 & $8.328 * *$ & $528 * *$ \\
\hline 12 per cent & 34 & 300 & 55 & 11 & 134 & 55 & 58 & 0.526 & 29 & $7.826^{* *}$ & $528 * *$ \\
\hline 11 per cent & 25 & 197 & 17 & 8 & 79 & 40 & 53 & 0.477 & 17 & $7.356^{* *}$ & $435^{* *}$ \\
\hline 10 per cent & 14 & 86 & 30 & 6 & 58 & 15 & 40 & 0.440 & 8 & $6.187 * *$ & $276^{* *}$ \\
\hline \multicolumn{12}{|l|}{ Panel B } \\
\hline \multicolumn{12}{|l|}{ De-smoothed FRE returns } \\
\hline$\alpha=0.33$ & 23 & 461 & 34 & 8 & 122 & 33 & 34 & 0.501 & 23 & $14.031 * *$ & $595 * *$ \\
\hline$\alpha=0.40$ & 28 & 524 & 40 & 11 & 150 & 41 & 41 & 0.528 & 30 & $12.669 * *$ & $595 * *$ \\
\hline$\alpha=0.50$ & 35 & 609 & 48 & 14 & 188 & 48 & 48 & 0.564 & 39 & $11.600 * *$ & $561 * *$ \\
\hline \multicolumn{12}{|l|}{ Panel C } \\
\hline Base Case without FRE (1974-1988) & & & & & & & 0 & 0.589 & - & - & - \\
\hline Base Case without FRE (1989-2003) & & & & & & & 0 & 0.326 & - & - & - \\
\hline \multicolumn{12}{|l|}{ Annual Inflation Rate (period) } \\
\hline $\begin{array}{c}13.1 \text { per cent } \\
(1974-1988)\end{array}$ & & & & & & & 61 & 0.813 & 38 & $6.047 * *$ & $228 * *$ \\
\hline $\begin{array}{l}2.4 \text { per cent } \\
(1989-2003)\end{array}$ & & & & & & & 65 & 0.520 & 60 & $6.722 * *$ & $323 * *$ \\
\hline
\end{tabular}

\footnotetext{
FRE, farm real estate

${ }^{a}$ Increase in corresponding mean Sharpe ratio relative to the Base Case without farm real estate. The increase in Sharpe ratio corresponding to the two inflation rate periods, 1974-1988 and 1989-2003 are relative to their respective Base Case without farm real estate.

$\mathrm{t}$ stat (signed rank) is the parametric (nonparametric) test statistic in comparing the difference in the mean Sharpe ratios relative to the Base Case without farm real estate. The test statistics corresponding to the two inflation rate periods are relative to their respective Base Case without farm real estate; ** Indicates significance at the .01 level.
} 
Table 8. Risk-return measures and correlation coefficients of appraisal-based and de-smoothed FRE return series

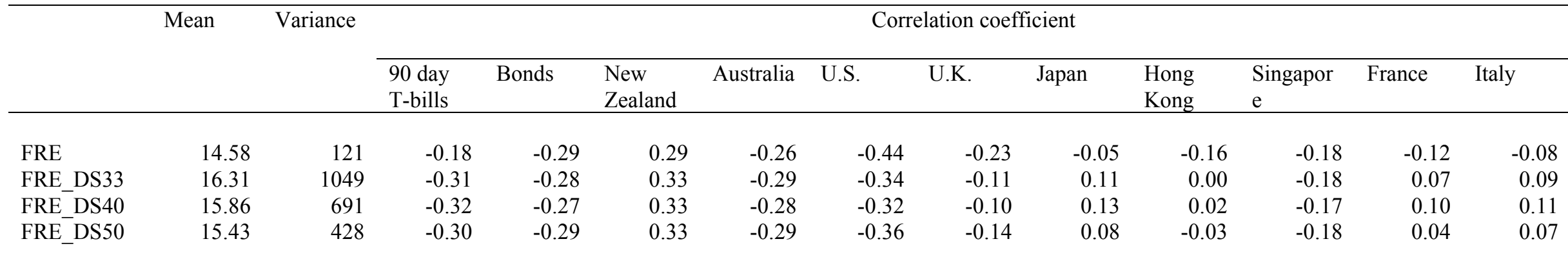

FRE, Farm real estate returns, appraisal -based; FRE_DS33, de-smoothed farm real estate returns with $\alpha=0.33$; FRE_DS40, de-smoothed farm real estate returns with $\alpha=$ 0.40 ; FRE_DS50, de-smoothed farm real estate returns with $\alpha=0.50$; 
Table 9. Allocation of FRE under two rolling periods.

\begin{tabular}{|c|c|c|c|c|c|c|}
\hline & \multicolumn{3}{|c|}{ 5-year rolling period } & \multicolumn{3}{|c|}{ 10-year rolling period } \\
\hline & $\begin{array}{l}\text { Mean } \\
\text { allocation } \\
\text { of FRE } \\
(\%)\end{array}$ & $\begin{array}{l}\text { Percentage } \\
\text { of the time } \\
\text { when FRE } \\
\text { achieved a } \\
\text { positive } \\
\text { allocation }\end{array}$ & $\begin{array}{l}\text { Percentage } \\
\text { of the time } \\
\text { when the } \\
\text { allocation } \\
\text { of FRE } \\
\text { exceeded } \\
20 \%\end{array}$ & $\begin{array}{l}\text { Mean } \\
\text { allocation } \\
\text { of FRE }\end{array}$ & $\begin{array}{l}\text { Percentage } \\
\text { of the time } \\
\text { when FRE } \\
\text { achieved a } \\
\text { positive } \\
\text { allocation }\end{array}$ & $\begin{array}{l}\text { Percentage } \\
\text { of the time } \\
\text { when the } \\
\text { allocation } \\
\text { of FRE } \\
\text { exceeded } \\
20 \%\end{array}$ \\
\hline 1MVP & 21 & 85 & 31 & 12 & 100 & 13 \\
\hline 2 & 27 & 92 & 62 & 22 & 100 & 38 \\
\hline 3 & 33 & 77 & 62 & 30 & 100 & 88 \\
\hline 4 & 35 & 85 & 77 & 38 & 100 & 100 \\
\hline 5 & 35 & 77 & 69 & 43 & 100 & 100 \\
\hline 6 & 33 & 69 & 69 & 44 & 100 & 100 \\
\hline 7 & 27 & 69 & 54 & 41 & 100 & 88 \\
\hline 8 & 22 & 62 & 46 & 28 & 100 & 50 \\
\hline 9 & 18 & 46 & 15 & 16 & 50 & 25 \\
\hline $10 \mathrm{MRP}$ & 15 & 8 & 8 & 0 & 0 & 0 \\
\hline
\end{tabular}




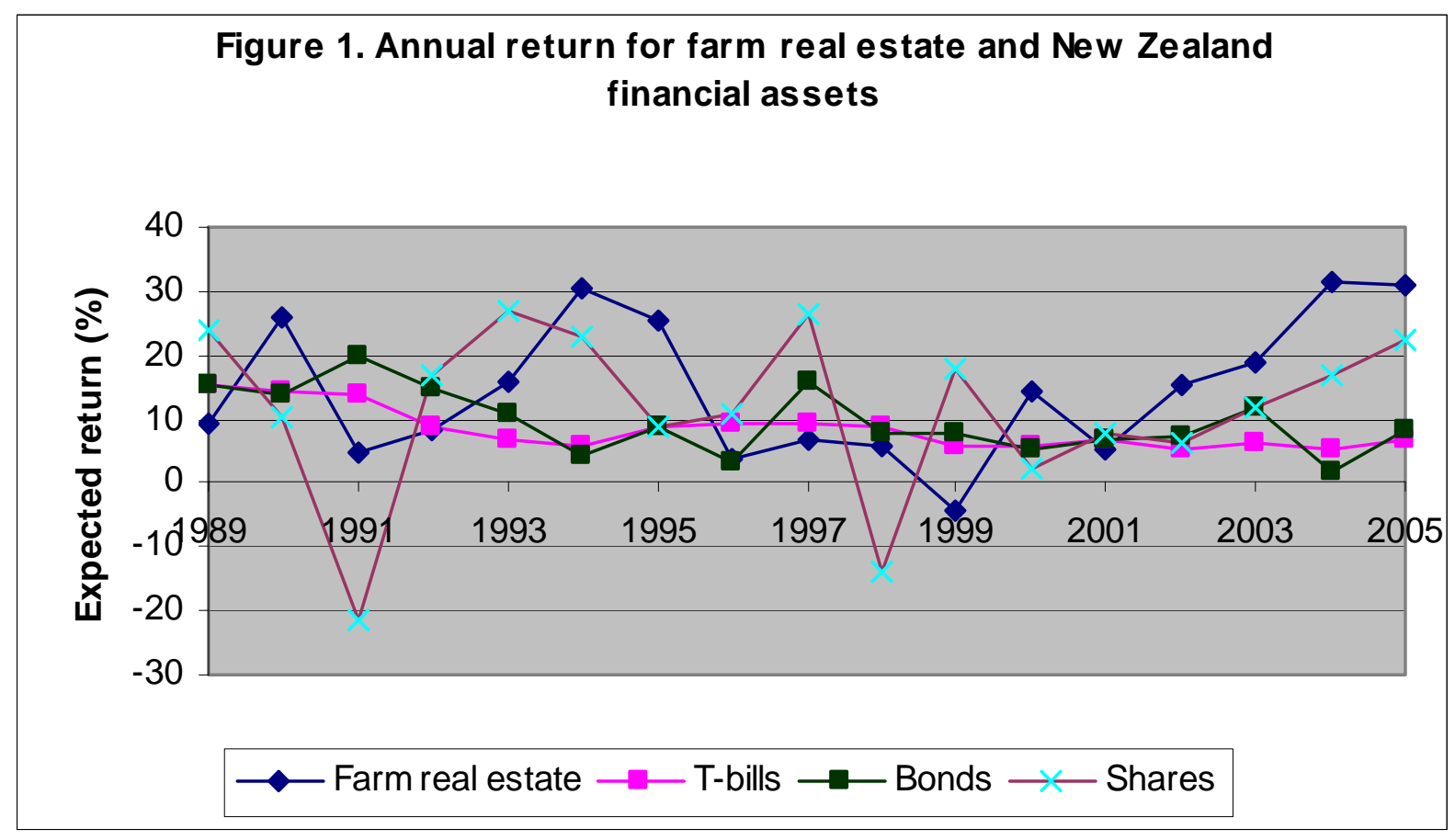


Figure 2. Annual return for farm real estate and selected share markets

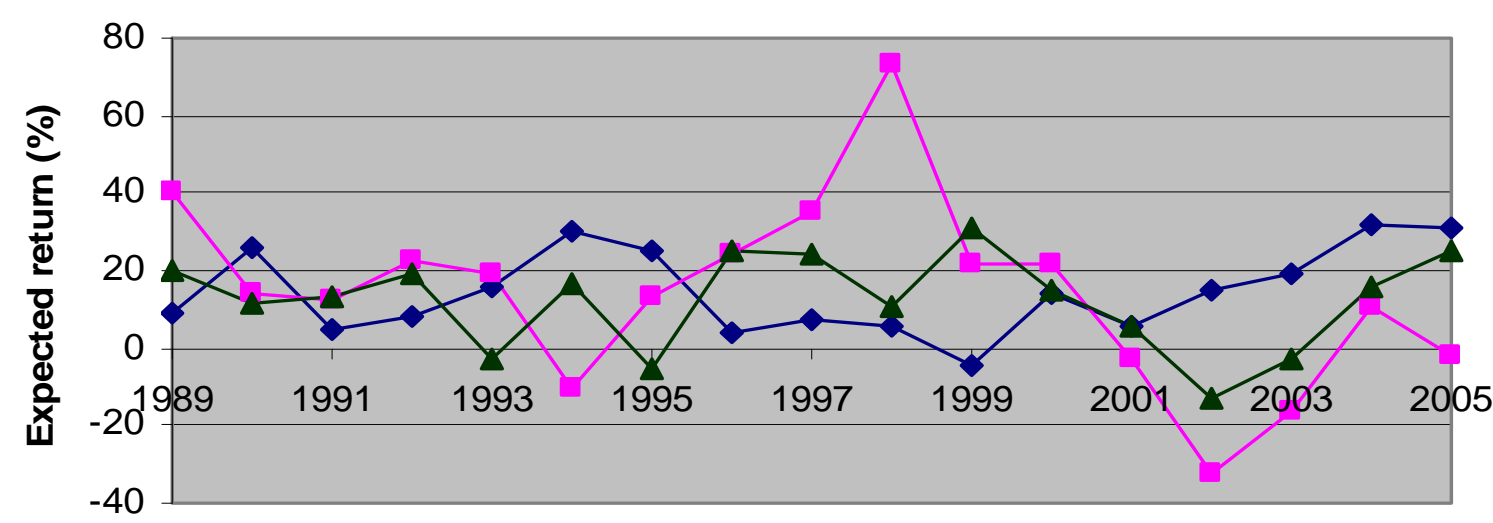

$\multimap$ Farm real estate $\multimap$ U.S. $\longleftarrow$ Australia 
Figure 3. Efficient Sets, With and Without Farm Real Estate, 1989-2005

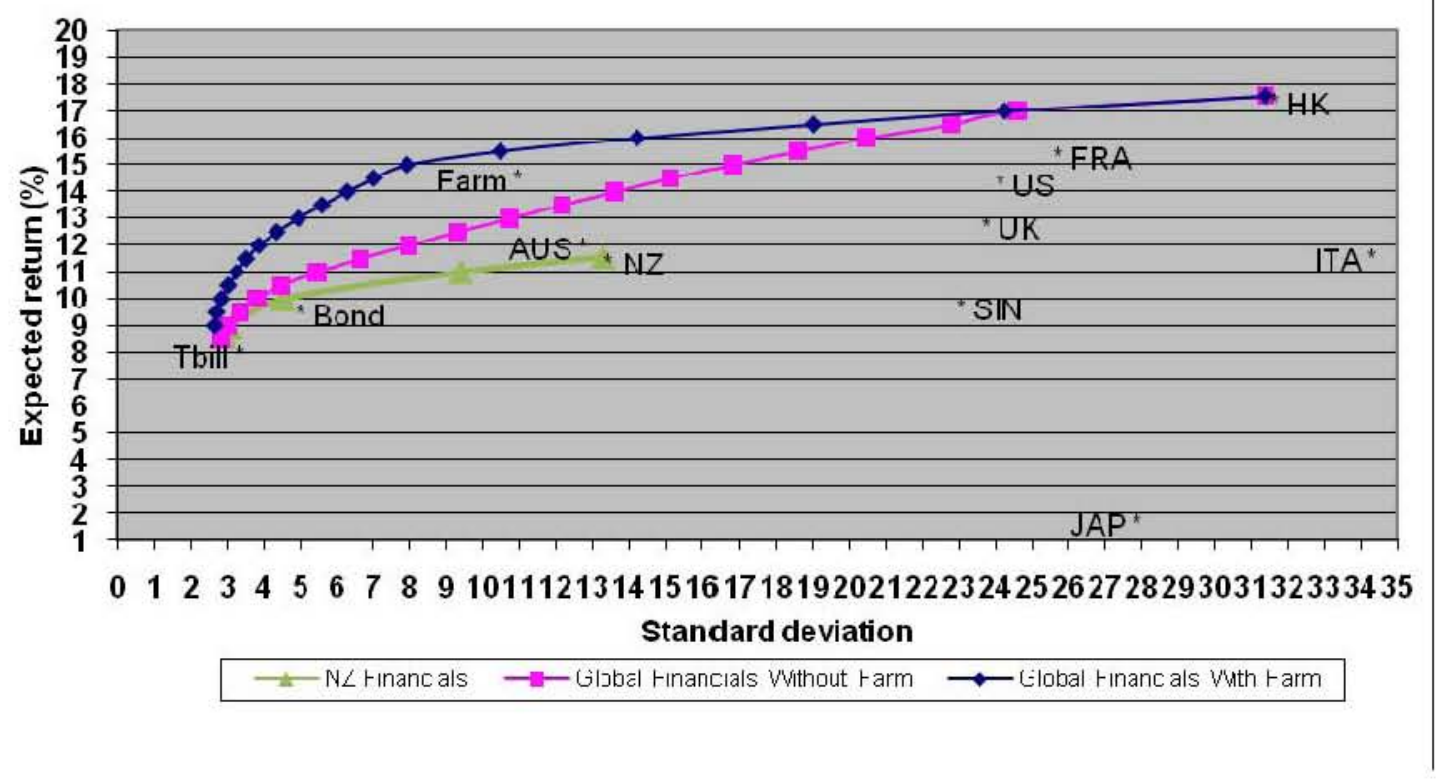




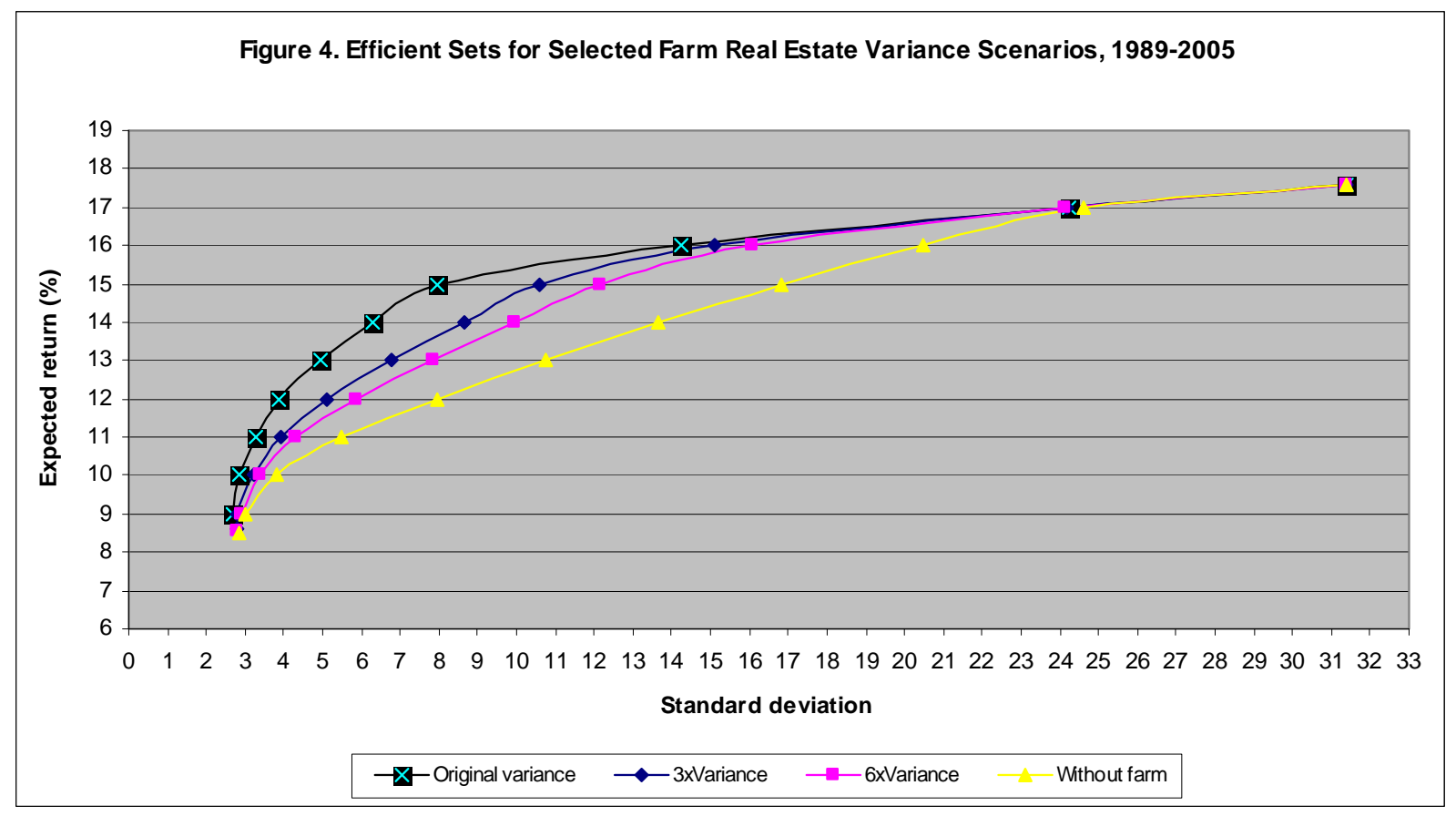




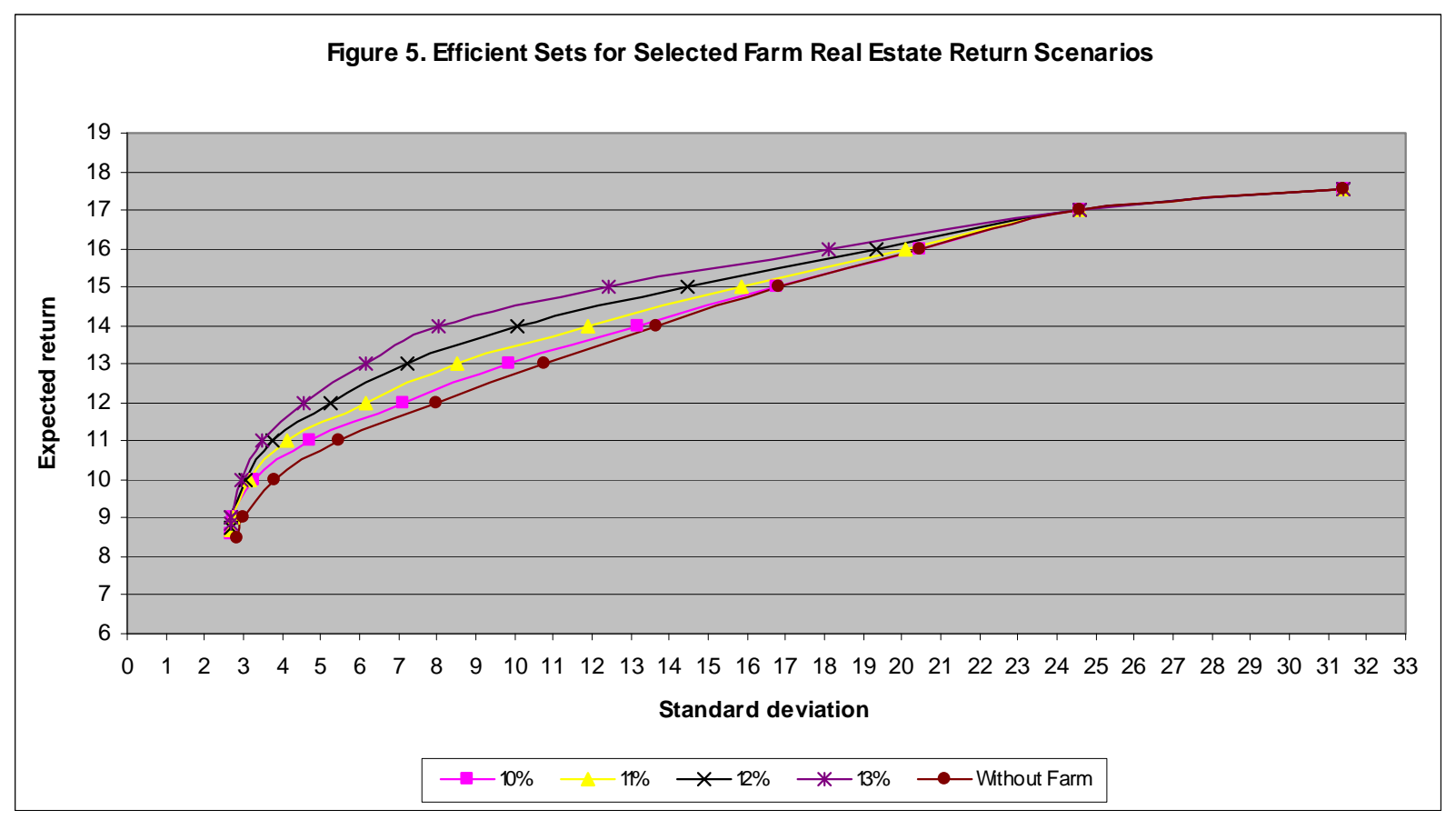

